\title{
UZALEŻNIENIE OD RODZINY POCHODZENIA
}

\section{Streszczenie}

Podstawowym i najważniejszym kontekstem społecznym dla rozwijajacej się jednostki jest rodzina, która stanowi główne środowisko socjalizacji wzrastajacych w niej osób, ale również może być źródtem ich psychicznych zaburzeń oraz społecznego nieprzystosowania. Jednym z rodzinnych czynników generujacych trudności jednostki w zakresie psychospołecznego funkcjonowania jest zbyt silna, uzależniająca więź, jaka istnieje pomiędzy jednostka a jej rodzina pochodzenia. To nadmierne przywiazanie względem rodziny generacyjnej zazwyczaj wyrasta z poczucia lojalności, które w swej patologicznej odmianie destruktywnie rzutuje na wiele obszarów życia i funkcjonowania jednostki. Podstawowym źródłem uzależnienia od rodziny pochodzenia jest ona sama wraz z określonym systemem swego funkcjonowania, który wyposaża wzrastajaca $w$ nim jednostke $w$ komponenty zdrowej bądź zaburzonej osobowości. Niniejszy artykut porusza problematyke lojalności rodzinnej oraz zwiazanych z niq uzależniajacych więzi rodzinnych; wskazuje systemy rodzinne, które generuja u osób w nich wzrastających zbyt silne przywiazanie wobec rodziny generacyjnej; oraz ukazuje znaczenie owego przywiazania dla psychospołecznego funkcjonowania uzależnionej jednostki.

Słowa kluczowe: lojalność rodzinna, systemy rodzinne, rodzina nadopiekuńcza, rodzina uwiktana.

* Mgr Adam Grabowski - teolog, student psychologii na Wydziale Filozofii Chrześcijańskiej Uniwersytetu Kardynała Stefana Wyszyńskiego w Warszawie, specjalność - psychologia małżeństwa i rodziny. 


\section{Zjawisko lojalności rodzinnej}

Termin lojalność, wywodzący się od francuskiego słowa loi, oznaczającego prawo, w klasycznym rozumieniu definiuje się jako pozytywną postawę jednostki w postaci tendencji do legalnych zachowań wobec obiektów lojalności, którymi najczęściej są określone systemy, takie jak: małżeństwo, rodzina, subkultura, naród czy religia ${ }^{1}$. Etyczny wymiar lojalności ujawnia się w aktach lojalności wobec członków danego systemu $\mathrm{w}$ formie zaufania, uznania wzajemnych zasług, zobowiązań, uczciwości i sprawiedliwości. Lojalność mobilizuje jednostkę, aby realizować oczekiwania grupy oraz wywiązywać się z zobowiązań wynikających z przynależenia do niej. Poczucie bycia lojalnym wobec systemu opiera się na zasadach zewnętrznego podporządkowania się nakazom danej grupy, jak i zinternalizowania tychże nakazów. Wszelkie zasługi grupy wobec jednostki oraz to wszystko, czym grupa obdarowała jednostkę, zostaje wpisane w ,niewidzialny rejestr” istniejący w postaci poczucia zobowiązania, które należy rozliczyć i lojalności, z której należy się wywiązać ${ }^{2}$.

Każda jednostka funkcjonuje w sieci różnorodnych więzów lojalnościowych, pośród których najbardziej uniwersalnymi są lojalności rodzinne, z racji swych biologicznych i egzystencjalnych podstaw, na które składają się więzy pokrewieństwa i powinowactwa. Najsilniejsze relacje lojalnościowe w rodzinie to te, które są oparte na biologicznym i dziedzicznym pokrewieństwie (np. relacja rodzicedzieci), wobec których więzy wynikające z powinowactwa (np. relacje z rodziną męża czy żony) są słabsze ${ }^{3}$.

Pojęcie lojalności rodzinnej to kluczowa kategoria jednej z odmian terapii rodzin, zwanej kontekstualną, której czołowym przedstawicielem jest węgierskiego pochodzenia amerykański psychiatra I. Boszormenyi-Nagy. Jego terapia odnosząca się do kontekstu koncentruje się na wielopokoleniowych wzorach powiązań w rodzinie, łącznie z zaufaniem, lojalnością, międzypokoleniowymi zobowiązaniami oraz uczciwością w relacjach między członkami rodziny. I. Boszormenyi-Nagy uważa, że aby zrozumieć sposób funkcjonowania określonej rodziny, oprócz prostej obserwacji sekwencji interakcji między jej członkami, należy również wziąć

\footnotetext{
1 I. Namysłowska, Terapia rodzin, Wydawnictwo Instytutu Psychiatrii i Neurologii, Warszawa 1997, s. 65.

2 I. Kołbik, Lojalność rodzinna, w: Wprowadzenie do systemowego rozumienia rodziny, red. B. de Barbaro, Collegium Medicum UJ, Kraków 1999, s. 78-79.

3 Tamże, s. 79.
} 
pod uwagę wpływ czynników międzypokoleniowych, a szczególnie subiektywnie odczuwanych zobowiązań wobec rodzin generacyjnych ${ }^{4}$.

Lojalność rodzinna w koncepcji terapii kontekstualnej rozumiana jest jako zinternalizowane oczekiwanie i zobowiązanie, powstałe wobec rodziny generacyjnej, a zachowujące swoją moc wobec rodziny prokreacyjnej. Efekty więzów lojalnościowych, sięgających przeszłych pokoleń, mogą stać się widoczne w aktualnych doświadczeniach rodzinnych, stanowiąc czynnik sprawczy niezrozumiałych i nieracjonalnych zachowań, jakie mogą występować w systemie rodzinnym. I. Boszormenyi-Nagy używa pojęcia lojalności do wyjaśnienia skomplikowanych relacji rodzinnych oraz powstawania patologii w rodzinie 5 .

Podstawową i najważniejszą więzią, istniejącą w systemie rodzinnym, która także stanowi główną siłę kształtującą dynamikę tego systemu - jak twierdzi I. Boszormenyi-Nagy - jest poczucie lojalności dzieci wobec rodziców. Pierwszeństwo oraz siła tejże lojalności, naturalnie wynikające z biologicznego pochodzenia i pokrewieństwa, wzmacniane są poczuciem wdzięczności wobec swych rodzicieli, przede wszystkim za dar przekazanego życia ${ }^{6}$.

Wdzięczność czyni dziecko swego rodzaju dłużnikiem względem swoich rodziców za otrzymane korzyści w postaci życia, miłości, opieki, zainteresowania i wsparcia. Zależność pomiędzy ilością otrzymanego od rodziców dobra a poczuciem wielkości długu, jaki dziecko ma do spłacenia, jest wprost proporcjonalna, tzn. im więcej troski dziecko otrzymało od swych rodziców, tym bardziej czuje się zobowiązane, by odwdzięczyć się za ich poświęcenie i zaangażowanie. Kiedy dziecko nie odwzajemnia się w wystarczający sposób rodzicom za ich trud i poświęcenie, staje się jeszcze większym dłużnikiem, a jego poczucie lojalności wzmacniane jest poczuciem winy oraz zawodu, jaki sprawia rodzicom oraz wszystkim tym, którzy obdarzyli je zaufaniem. Czynnik poczucia wdzięczności wobec rodziców odgrywa znaczącą rolę w procesie zinternalizowania zobowiązań wobec nich oraz przyswojenia sobie ich systemu wartości.

W toku realizacji zadań rozwojowych przypadających na kolejne fazy życia rodzinnego następują również zmiany w zakresie lojalności. Każde przejście z jednej fazy do drugiej wymaga podjęcia przez poszczególnych członków rodziny nowych ról i zadań, co ściśle związane jest z koniecznością zrównoważenia starych

4 H. Goldenberg, I. Goldenberg, Terapia rodzin, Wydawnictwo Uniwersytetu Jagiellońskiego, Kraków 2006, s. 214-216.

5 I. Namysłowska, Terapia... dz. cyt., s. 65.

$6 \quad$ I. Kołbik, Lojalność... art. cyt., s. 79.

7 M. Wolska, Problem lojalności rodzinnej a anoreksja psychiczna, „Przegląd Lekarski” 2004, nr 64(11), s. 1284. 
oczekiwań z nowymi. Wejście w związek małżeński, pojawienie się dzieci, dorastanie, indywiduacja, separacja, starzenie się czy też żałoba po śmierci bliskiej osoby są przykładami typowych sytuacji, które wymagają ponownego zrównoważenia lojalnościowych zobowiązań. Pionowe lojalnościowe zobowiązania wobec wcześniejszych lub późniejszych pokoleń pozostają w konflikcie ze zobowiązaniami poziomymi, związanymi z partnerem, rodzeństwem czy rówieśnikami. Nawiązywanie nowych relacji, szczególnie w ramach małżeństwa i rodzicielstwa nieodzownie łączy się z pojawieniem się nowych lojalnościowych zobowiązań ${ }^{8}$.

Prawidłowy rozwój jednostki w aspekcie poczucia lojalności będzie więc zmierzać w kierunku osiągnięcia przez nią zdolności do zrównoważenia starych i nowych lojalnościowych zobowiązań. Im bardziej jednostka jest sztywno przywiązana do swoich rodziców niewidzialnymi lojalnościowymi obligacjami, tym trudniej będzie jej zastąpić pierwotną lojalność nowym relacyjnym zobowiązaniem, a także w odpowiednich proporcjach angażować się w stare i nowe lojalności. Nadmierna relacja dziecka $\mathrm{z}$ rodzicami zdecydowanie utrudnia proces jego indywiduacji (niezbędnej do nawiązywania nowych, dojrzałych relacji emocjonalnych) oraz generuje w nim tzw. konflikty lojalnościowe9

Owe konflikty najczęściej dotyczą sytuacji, takich jak: kiedy dziecko nie jest w stanie być lojalnym wobec obojga rodziców, prezentujących sprzeczne postawy; kiedy dokonywane przez dorastające dziecko wybory nie są zgodne z oczekiwaniami rodziców (np. odnośnie do wyboru szkoły czy partnera); bądź w sytuacji parentyfikacji, która oznacza przyznanie dziecku lub przejęcie przez nie roli rodzicielskiej, gdzie dziecko zaczyna funkcjonować jako dorosły członek systemu rodzinnego, sprawujący opiekę nad niedojrzałymi, wręcz infantylnymi rodzicami ${ }^{10}$.

Najsilniej konflikt lojalności przeżywany jest w okresie adolescencji, kiedy to przed młodą jednostką stoi wyzwanie pogodzenia dotychczasowych pionowych lojalności, łączących ją z rodziną generacyjną, z lojalnościami poziomymi, będącymi podstawą związku z rówieśnikami i życiowymi partnerami. Wchodzenie młodego człowieka w nowe relacje (w tym seksualne) lub dokonywanie przez niego samodzielnych wyborów może być odbierane przez rodziców jako zerwanie dotychczasowej lojalności rodzinnej, lekceważenie rodzinnych wartości czy też jako niedocenianie ich trudu i poświęcenia. Tymczasem to, co na zewnątrz wydaje się być sprzeniewierzeniem się wobec rodziny, w rzeczywistości jest zmaganiem się adolescenta $z$ odczuwanym poczuciem lojalności rodzinnej oraz potrzebą niezależności i podmiotowości. Zazwyczaj te zmagania przybierają postać buntu,

\footnotetext{
I. Kołbik, Lojalność... art. cyt., s. 83.

Tamże, s. 80-82.

10 M. Wolska, Problem... art. cyt., s. 1284.
} 
który tym bardziej narasta u dojrzewającej jednostki, im bardziej jest ona związana lojalnościowymi więzami z rodziną pochodzenia ${ }^{11}$.

Nierozwiązany konflikt lojalności wobec rodziny generacyjnej zostaje przeniesiony do rodziny prokreacyjnej, gdzie stanowi źródło wielu napięć i patologicznych zachowań. Niemożność wyrównania rachunków z przeszłymi pokoleniami generuje $w$ jednostce poczucie winy - w przypadku kiedy nie odwdzięczyła się wystarczająco za otrzymane dobra, lub poczucie krzywdy - gdy otrzymała zbyt mało w stosunku do tego, co dała od siebie innym członkom rodziny lub całemu systemowi rodzinnemu ${ }^{12}$.

Przenoszenie z pokolenia na pokolenie zespołu oczekiwań, norm i stereotypów określa się mianem dziedzictwa, w ramach którego jednostka spłaca bądź odbiera długi tylko w ten sposób, w jaki ją tego nauczono, np. w sytuacji, kiedy dziecko, wobec którego rodzice mieli nadmierne i nierealistyczne wymagania, jako dorosła osoba powtarza je wobec własnych dzieci ${ }^{13}$.Poczucie krzywdy lub niesprawiedliwości rodzi oczekiwanie zadośćuczynienia oraz potrzebę uzyskania odszkodowania. Zobowiązania sięgające poprzednich pokoleń nie muszą być uświadomione ani zaakceptowane, aby wywierać wpływ na aktualne zachowanie członków rodziny. Wszystko to, co zostało ofiarowane, oraz to, kto psychologicznie wciąż jest coś komuś winny, zostaje wpisane w „niewidzialny rejestr” długów i zasług. Międzypokoleniowe rozliczanie lojalności przybiera postać określonych postaw, uczuć, zachowań i oczekiwań, tworzących określony sposób funkcjonowania rodziny ${ }^{14}$.

Jeżeli w obrębie rodziny generacyjnej z jakichś powodów rachunki nie zostaną wyrównane, wówczas zobowiązania, dług wdzięczności, czy odpłata doznanych krzywd zostaje przekazana w sposób jawny lub ukryty następnemu pokoleniu. Osoby, które otrzymały wiele dobra od swoich rodziców i nie mogą się im odwdzięczyć w sposób bezpośredni, na zasadzie dziedzictwa przekazują miłość, opiekę i wsparcie swoim dzieciom, z kolei zaś ci, którzy w swoich rodzinach generacyjnych byli wykorzystywani lub gnębieni, mogą tę krzywdę przekazać dalej, wyzyskując i krzywdząc swojego partnera lub dzieci. Zarówno jedni, jak

11 M. Wolska, Rodzinna lojalność, w: Kontakty z ludźmi ,innymi” jako problem wychowania, opieki i resocjalizacji, red. B. Kosek-Nita, D. Raś, Wydawnictwo Uniwersytety Śląskiego, Katowice 2000, s. 58-59.

12 M. Wolska, Problem... art. cyt., s. 1284.

13 I. Namysłowska, Terapia... dz. cyt., s. 65.

14 H. Goldenberg, I. Goldenberg, Terapia rodzin ... dz. cyt., s. 216-217. 
i drudzy będą ciągle lojalnymi członkami wielopokoleniowego systemu rodzinnego, gdyż postępowanie ich jest zgodne z panującymi w ich rodzinie zasadami i prawami ${ }^{15}$.

Lojalność rodzinna, oparta o niepisane prawo międzypokoleniowe oraz będąca podstawą istnienia każdej rodziny i zachowania bliskich relacji wewnątrzrodzinnych, jawi się jako zjawisko pozytywne. Jednak może ona przybrać dwie odmienne postaci, w zależności od tego, jaki obierze kierunek swego rozwoju. W pozytywnej odmianie lojalność rodzinna stanowi spajającą siłę, która daje członkom rodziny poczucie przynależności, bezpieczeństwa i wsparcia, oraz sprzyja indywidualnemu rozwojowi, zaś w odmianie negatywnej lojalność rodzinna to wikłająca, uzależniająca więź, która destruktywnie wpływa na osobowy rozwój i zachowanie jednostki. Przeżywane przez jednostkę tzw. konflikty lojalności wobec rodziny generacyjnej przenoszone są do rodziny prokreacyjnej, gdzie stanowią czynnik sprawczy wielu zaburzeń i patologii życia rodzinnego. Kierunek rozwoju oraz kształtowanie się lojalności rodzinnej zależy przede wszystkim od systemu rodzinnego, który wyposaża wzrastającą w nim jednostkę w komponenty zdrowej bądź zaburzonej osobowości. System funkcjonowania rodziny, w którym brakuje przestrzeni na odrębność i niezależność, wikła jednostkę w uzależniające więzi i relacje do tego stopnia, że każda jej próba bycia samodzielną czy też niezależną będzie się wiązać z poczuciem winy i sprzeniewierzania się rodzinnej lojalności, co w konsekwencji może stanowić źródło psychopatologicznych stanów jednostki oraz jej społecznego nieprzystosowania.

\section{Systemy rodzinne uzależniające od rodziny pochodzenia}

Obecnie w nurcie psychologii rodziny, zarówno w badaniach nad rodziną jak i w terapii rodzin, jedną z najbardziej popularnych oraz najczęściej stosowanych teorii jest teoria systemowa, która stanowi podstawę, inspirację oraz perspektywę spostrzegania i interpretowania zjawiska rodziny oraz zmian w niej zachodzących ${ }^{16}$. Zagadnienie rodziny osadzonej w modelu systemowym znalazło szerokie uznanie

15 M. Wolska, Problem ... dz. cyt., s. 1284.

16 T. Pietras, Współczesne nurty w terapii rodzin, w: Psychologia rodziny, red. I. Janicka, H. Liberska, Polskie Wydawnictwo Naukowe, Warszawa 2014, s. 527-536. 
i zainteresowanie w opracowaniach wielu polskich psychologów, m.in. takich jak: M. de Barbaro ${ }^{17}$; I. Namysłowska ${ }^{18}$; Plopa ${ }^{19} ;$ M. Radochońskii ${ }^{20} ;$ M. Ryśs ${ }^{11}$.

Pierwsze spostrzeżenia dotyczące funkcjonowania rodziny jako spójnego systemu miały miejsce na przełomie XIX i XX w., kiedy to ówcześni psychoanalitycy, m.in. D.W. Winnicot, N.W. Ackerman czy też M. Klein, jako pierwsi zauważyli, że wszelkie zaburzenia relacji rodzinnych zakłócają psychiczną równowagę dziecka. Tego rodzaju obserwacje i płynące z nich wnioski pozwoliły na postawienie tezy, że nieprawidłowe społeczne i emocjonalne zachowanie dziecka stanowi symptom zaburzeń interpersonalnych w rodzinie oraz deformacji życia rodzinnego ${ }^{22}$.

W latach 50. i 60. XX w. pojawiły się pierwsze prace, m.in. R. Spitza i L Fromm-Reichmana, traktujące na temat zaburzonej relacji matki z dzieckiem, interpretowanej jako tło wszelkich psychicznych zaburzeń dziecka ${ }^{23}$. Również prace G. Batesona oraz D.D. Jacksona, w których wymienieni autorzy, analizując etiologię schizofrenii, dowodzili, że dostrzegalne symptomy u jednego członka rodziny mogą być wskaźnikiem patologii całej rodziny, przyczyniły się do myślenia o rodzinie jako o systemie ${ }^{24}$.

Model rozumienia rodziny jako układu wzajemnie oddziaływujących na siebie elementów znalazł filozoficzno-teoretyczną podstawę w ogólnej teorii systemów, której twórcą był austriacki filozof i biolog L. von Bertalanffy. Ogłoszona w 1954 r. koncepcja systemowa - wg jej autora - odnosi się do najbardziej ogólnych reguł funkcjonowania całej rzeczywistości, a na gruncie poszczególnych nauk przybiera ona specyficzną dla siebie postać. L. von Bertalanffy głosi, że system to układ wyższego rzędu wzajemnych i dynamicznych relacji, zachodzących pomiędzy

17 M. de Barbaro, Struktura rodziny, w: Wprowadzenie do systemowego rozumienia rodziny, red. B. de Barbaro, Collegium Medicum UJ, Kraków, 1999, s. 45-46.

18 I. Namysłowska, Terapia... dz. cyt., s. 65.

19 M. Plopa, Psychologia rodziny: teoria i badania, Oficyna Wydawnicza Impuls, Kraków 2007.

20 M. Radochoński, Psychoterapia rodzinna w ujęciu systemowym, Wydawnictwo Wyższej Szkoły Pedagogicznej w Rzeszowie, Rzeszów 1984.

21 M. Ryś, Systemy rodzinne. Metody badań struktury rodziny pochodzenia i rodziny własnej, Centrum Metodyczne Pomocy Psychologiczno-Pedagogicznej, Warszawa 2001.

22 M. Gawęcka, Poczucie osamotnienia dziecka $w$ rodzinie, Wydawnictwo Adam Marszałek, Toruń 2011, s. 8.

23 L. Grzesiuk, U. Jakubowska, Terapia systemowa, w: Psychoterapia. Teoria-podręcznik akademicki, red. L. Grzesiuk, Wydawnictwo Naukowe, Warszawa 2005, s. 189-190.

24 E. Przybylska, D. Wajsprych, Uczenie się i rodzina. Perspektywa andragogiczna, Wydawnictwo CeDeWu, Warszawa 2018, s. 49. 
tworzącymi go elementami oraz działających na zasadzie sprzężenia zwrotnego ${ }^{25}$. Przykładami adaptacji teorii systemowej w ramach psychologii może być traktowanie osobowości jako systemu, a cech jako jego elementów, czy też - jak zostało nadmienione - ujęcie rodziny jako systemu, którego elementami są poszczególni członkowie i tworzone przez niech podsystemy ${ }^{26}$.

Własności, które charakteryzują określony układ jako system, to: całościowość, organizacja, zasady ekwipotencjalności i ekwifinalności, dynamizm, cyrkularność, zdolność do homeostazy oraz posiadanie zewnętrznych i wewnętrznych granic ${ }^{27}$.

Rodzina w koncepcji systemowej stanowi psychospołeczny układ złożony ze spokrewnionych lub spowinowaconych ze sobą jednostek oraz organizowanych przez nie podsystemów. Adaptacja teorii systemowej na gruncie psychologii rodziny pozwala na określenie i badanie zjawiska rodziny jako całościowego, spójnego i dynamicznego systemu wzajemnie oddziaływujących na siebie elementów, tworzących ustrukturalizowany układ dynamicznych interakcji, działających na zasadzie sprzężenia zwrotnego, a więc rodzina osadzona w modelu systemowym prezentuje się jako układ posiadający wszelkie własności określające ją jako system ${ }^{28}$.

System rodzinny funkcjonuje według określonej struktury i organizacji, na które składają się pojedyncze osoby, jak również tworzone przez nich podsystemy, np. podsystem rodziców czy też dzieci ${ }^{29}$. Istnienie rodziny w postaci zorganizowanego i spójnego układu, w ramach którego dochodzi do dynamicznych interakcji pomiędzy poszczególnymi członkami rodziny, a także tworzonymi przez nich podsystemami, świadczy o całościowości systemu rodzinnego. Rodzina jako system nie jest tylko sumą przynależących do niej osób, ale stanowi coś więcej, coś, co nadaje jej nowej jakości, którą tworzą jej członkowie oraz relacje między nimi ${ }^{30}$. Tworzenie przez rodzinę sieci wzajemnych relacji i powiązań, działających na zasa-

25 L. von Bertalanffy, Ogólna teoria systemów, Państwowe Wydawnictwo Naukowe, Warszawa 1984.

26 W. Świętochowski, Rodzina w ujęciu systemowym, w: Psychologia rodziny, red. I. Janicka, H. Liberska, Polskie Wydawnictwo Naukowe, Warszawa 2014, s. 22.

27 M. Braun-Gałkowska, Psychologiczna analiza systemów rodzinnych osób zadowolonych i niezadowolonych z matzeństwa, Towarzystwo Naukowe KUL, Lublin 1992 , s. $14-15$.

28 M. Ryś, Systemy rodzinne. Metody badań struktury rodziny pochodzenia i rodziny własnej, Centrum Metodyczne Pomocy Psychologiczno-Pedagogicznej, Warszawa 2001, s. 8.

29 D. Field, Osobowości rodzinne, Oficyna Wydawnicza Logos, Warszawa 1999, s. 23.

30 T. Bajkowski, U źródeł tożsamości rodzinnej, Wydawnictwo Naukowe Scholar, Warszawa 2018, s. 24. 
dzie sprzężeń zwrotnych przesądza o cyrkularnym charakterze jej funkcjonowania, gdzie trudno jest dostrzec liniowy proces przyczynowo-skutkowy, pozwalający, aby jednoznacznie wskazać, czyje zachowanie stanowi bodziec, a czyje reakcję ${ }^{31}$. $\mathrm{W}$ tak funkcjonującym systemie nie istnieją proste zależności pomiędzy przyczyną a skutkiem, co wiąże się z zasadą ekwipotencjalności, według której, mimo podobnych warunków startowych, system lub jego członkowie mogą osiągnąć różne stany końcowe, jak i zasadą ekwifinalności, a więc możliwości osiągania podobnych rezultatów finalnych przy wychodzeniu z różnych stanów początko$w_{y c h}{ }^{32}$. System rodzinny dzięki samoregulacyjnym mechanizmom, w jakie jest wyposażony, zachowuje zdolność do homeostazy, a więc utrzymania równowagi między jego dynamizmem a stałością, dzięki czemu rodzina potrafi dostosować się względem zmieniających się warunków i okoliczności, tak by jednocześnie zachować swą tożsamość i pozostać kontekstem optymalnego rozwoju swoich członków ${ }^{33}$. Własnością, która pozwala istnieć rodzinie jako odrębny, tożsamy oraz autonomiczny system w czasie i przestrzeni, są zewnętrzne granice, które wyróżniają i oddzielają określoną rodzinę względem innych systemów, a także umożliwiają lub utrudniają kontakt i wymianę ze środowiskiem zewnętrznym ${ }^{34}$. Również wewnątrz systemu obecne są granice, które określają istniejące w nim podsystemy, jak i poszczególnych członków. Od optymalnego modelu funkcjonowania rodziny wymaga się istnienia jasno określonych i elastycznych granic, które umożliwiają autonomię, komunikację i współpracę pomiędzy członkami oraz organizowanymi przez nich podsystemami. Wyrazistość granic daje możliwość swobodnego spełniania przez poszczególnych członków podsystemów ważnych dla nich funkcji, zaś odpowiednia przepuszczalność - prawidłową komunikację między nimi ${ }^{35}$.

Ostatnia z wymienionych własności systemu dotycząca jego zewnętrznych i wewnętrznych granic - zdaniem jednego z twórców terapii systemowej rodzin S. Minuchina - jest tą, która przesądza o prawidłowości bądź dysfunkcyjności rodziny. Rodzina odznaczająca się sztywnością istniejących w niej granic jest słabo zintegrowana przez co brakuje w niej poczucia przynależności oraz wsparcia. Z kolei w sytuacji, kiedy w rodzinie brakuje granic stanowi ona spójną całość, gdzie dominuje w niej poczucie lojalności, jednak nie ma w niej miejsca i możliwości na

31 M. Ryś, Systemy rodzinne... dz. cyt., s. 9.

32 E. Przybylska, D. Wasjprych, Uczenie się... dz. cyt., s. 50.

33 M. de Barbaro, Struktura rodziny, w: Wprowadzenie do systemowego rozumienia rodziny, red. B. de Barbaro, Collegium Medicum UJ, Kraków, 1999, s. 45-46.

34 T. Bajkowski, U źródeł... dz. cyt., s. 28.

35 M. de Barbaro, Struktura rodziny... art. cyt., s. 48. 
rozwój autonomii i odrębności u poszczególnych członków, a szczególnie u wzrastających w niej dziecis ${ }^{36}$.

Rodzaj granic (sztywność vs elastyczność) występujących w rodzinnym systemie, a dokładnie mówiąc: granic pomiędzy podsystemami rodziców i dzieci stanowi także podstawowe kryterium decydujące o prawidłowym bądź nieprawidłowym funkcjonowaniu systemu rodzinnego w typologii D. Fielda. Wyróżnił on pięć systemów rodzinnych, do których zalicza jeden prawidłowy, zwany rodziną związków, oraz cztery nieprawidłowe, określane jako: rodzina chaotyczna, rodzina władzy, rodzina nadopiekuńcza i rodzina uwikłana ${ }^{37}$.

Jaki rodzaj granic występuje w poszczególnych systemach, przedstawia rycina nr 1, która prezentuje rodzaje rodzin według typologii D. Fielda, począwszy od systemów o najbardziej sztywnych i nieprzepuszczalnych granicach, a skończywszy na systemach, gdzie granice $\mathrm{z}$ kolei są zbyt elastyczne i przepuszczalne.

\section{Systemy rodzinne}

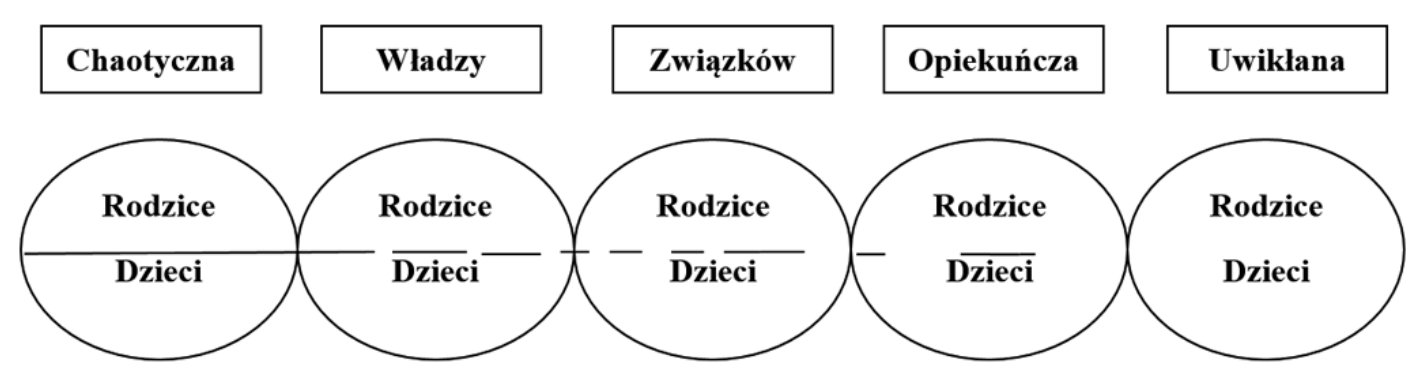

Rycina 1. Typologia systemów rodzinnych wg D. Fielda ${ }^{38}$

Rodzaj zaprezentowanych w graficzny sposób granic istniejących pomiędzy podsystemami rodziców i dzieci - zdaniem D. Fielda - w decydującym stopniu determinuje jakość funkcjonowania rodziny oraz warunkuje posiadanie przez rodzinę poziomu zdolności i możliwości w zakresie: zaspokajania podstawowych potrzeb wszystkich członków, spełniania swych funkcji i społecznych oczekiwań, prawidłowej komunikacji oraz socjalizacji dzieci i przygotowania ich do życia w dorosłości. Niezwykle sztywne i nieprzepuszczalne granice w rodzinie chaotycznej powodują brak jakichkolwiek więzi oraz komunikacji pomiędzy małżonkami, jak również pomiędzy rodzicami a dziećmi, przez co rodzina jest wewnętrznie

36 L. Grzesiuk, U. Jakubowska, Terapia systemowa... art. cyt., s. 195-196.

37 D. Field, Osobowości rodzinne... dz. cyt., s. 30-92.

38 Tamże, s. 27. 
rozdarta i zdezorganizowana. System rodziny władzy również określają dość sztywne i nieprzepuszczalne granice, w oparciu o które zostaje ustalona wyraźna struktura rodziny, w ramach której rodzice narzucają swoją władzę dzieciom, a zasady i reguły przedkłada się nad relacje międzyludzkie, co rodzi wzajemną niechęć i dystans. Rodzina związków to prawidłowy system rodzinny, gdzie granice pomiędzy rodzicami a dziećmi są jasno określone i jednocześnie elastyczne i przepuszczalne, co sprawia, że pomiędzy członkami takiej rodziny istnieją zarówno silne relacje, jak i przestrzeń na odrębność i niezależność. W systemie rodziny opiekuńczej występują zbyt elastyczne i przepuszczalne granice, powodujące przesadnie bliskie, uzależniające relacje rodzinne oraz brak dostatecznej przestrzeni na indywidualność i odrębność. Z kolei brak jakichkolwiek granic w rodzinie uwikłanej generuje wzajemne uzależnienie podsystemów rodziców i dzieci oraz nadmierne, wręcz obsesyjne przywiązanie rodziców do dzieci ${ }^{39}$.

Powyższe zestawienie rodzajów rodzin według typologii D. Fielda oraz ich ogólna charakterystyka ukazują te systemy rodzinne, które generują we wzrastających w nich jednostkach uzależnienie od rodziny pochodzenia. Porównanie ich pozwala także dostrzec podstawową zasadę rozwoju owego uzależnienia, którą stanowi brak w rodzinie przestrzeni na odrębność, indywidualność i samodzielność jednostki, spowodowany zbyt przepuszczalnymi i elastycznymi granicami lub nawet ich brakiem pomiędzy rodzicami a dziećmi. Systemami rodzinnymi, które uzależniają jednostkę od jej rodziny generacyjnej, są te, które w swym funkcjonowaniu wiążą wzrastających w nich członków uczuciowo, emocjonalnie, społecznie i zadaniowo. Według nazewnictwa D. Fielda uzależniające, w omawianym kontekście, systemy określane są mianem rodziny opiekuńczej i rodziny uwikłanej. Poniżej zostanie przedstawiona krótka charakterystyka tych dwóch uzależniających systemów, która w ogólnym zarysie ukaże najgłówniejsze i najbardziej typowe cechy ich funkcjonowania.

\section{Rodzina nadopiekuńcza}

Jak już zostało nadmienione, ten system funkcjonowania rodziny charakteryzują zbyt elastyczne i przepuszczalne granice, które skutkują nadmiernie bliskimi, uzależniającymi więziami rodzinnymi oraz brakiem przestrzeni w rodzinie na samodzielność i podmiotowość poszczególnych członków. Rodzina nadopiekuńcza bardzo dobrze radzi sobie w zakresie kultywowania rodzinnych tradycji, a także wzajemnych lojalności. Naczelną zasadą w omawianym systemie jest rodzinny spokój, zaś dominującym elementem w relacjach interpersonalnych są uczucia,

39 Tamże, s. 30-92. 
dlatego też w rodzinie nadopiekuńczej nie rozmawia się na niewygodne, kontrowersyjne tematy, a także nie komunikuje się szczerze na temat swoich odczuć, wrażeń, potrzeb i poglądów. Na rzecz przyjaznych, aczkolwiek często nieszczerych relacji oraz rodzinnego komfortu omawiana rodzina za wszelką cenę unika niezgody i konfliktów. Centralne miejsce w omawianym systemie rodzinnym zajmują dzieci, co do których rodzice pragną, aby niczego im nie brakowało. Bardzo często dzieci wykorzystują swoją centralną pozycję oraz nadmierną troskę rodziców, nieustannie oczekując od nich pomocy i wyręczania w obowiązkach, na co rodzice, którzy rzadko odnoszą się do swojego autorytetu, się godzą ${ }^{40}$.

\section{Rodzina uwikłana}

Ten system rodzinny określany jest także rodziną nadmiernie uzależnioną, co spowodowane jest brakiem jakichkolwiek granic pomiędzy podsystemami rodziców i dzieci. W tak funkcjonującej rodzinie, przez zupełne splątanie, brakuje przestrzeni na jakąkolwiek prywatność i odrębność, co szczególnie dotyczy dzieci, które w opisywanym systemie są ofiarami nadmiernego, wręcz obsesyjnego przywiązania rodziców. Zwykle taki stan rzeczy spowodowany jest osłabionym systemem relacji małżeńskiej, przez co małżonkowie, dążąc do bliskości oraz zaspokajając swoje emocjonalne potrzeby, wykorzystują dzieci, ingerując $\mathrm{w}$ ich podsystem. Myśląc i działając za dziecko, całkowicie uzależniają je od siebie na zasadzie psychicznego zawłaszczania. Zaburzony system małżeński wprowadza ciągle napiętą atmosferę, która skutkuje strachem przed ujawnianiem przez poszczególnych członków rodziny swoich uczuć i myśli. W rodzinie uwikłanej, podobnie jak w opiekuńczej, panującą zasadą jest spokój rodzinny nawet za cenę szczerości, na którą w obydwu systemach nie ma miejsca ${ }^{41}$.

\section{Rozwój oraz znaczenie uzależnienia jednostki od rodziny pochodzenia}

Dla prawidłowego rozwoju osobowego dziecka, tzn. zmierzającego ku wykształceniu w nim zdrowej osobowości, konieczne jest zachowanie równowagi pomiędzy jego dążeniem do autonomii, przejawiania inicjatywy i doświadczania poczucia kompetencji a ochroną i nadzorowaniem jego zachowań przez rodziców. Nadmierna kontrola uniemożliwia rozwój inicjatywy i samodzielności dziecka, zaś zbyt słaba hamuje jego rozwój w zakresie kompetencji społecznych, szczególnie

\footnotetext{
40 Tamże, s. 57-58; 63-64.
}

41 Tamże, s. 82-84; 88-90. 
gdy chodzi o nawiązywanie i podtrzymywanie relacji interpersonalnych oraz społeczne przystosowanie ${ }^{42}$.

Proces kształtowania samodzielnej i odrębnej jednostki wymaga, aby rodzice poprzez adekwatne interwencje wychowawcze stworzyli dziecku jak najlepsze warunki dla rozwoju jego indywidualności i samodzielności. Tak więc podstawowe zadanie rodziców polega na czuwaniu nad przejawami autonomii, inicjatywy i kompetencji dziecka, z jednoczesnym jego uspołecznianiem, przede wszystkim poprzez uczenie adekwatnej oceny własnych kompetencji, współpracy z innymi osobami oraz szacunku wobec ich praw. Rodzice stwarzają warunki dla rozwoju osobowego dziecka w ramach wdrażania - w sposób świadomy bądź nie - określonej strategii wychowawczej wobec swoich dzieci ${ }^{43}$.

Określone style wychowawcze ściśle związane są z poszczególnymi systemami rodzinnymi, wyróżnionymi ze względu na jakość występujących w nich granic, wpisując się w specyfikę ich funkcjonowania oraz z nich wynikając. Styl rodzicielski w dużej mierze zależy od jakości i charakteru relacji podejmowanych w podsystemie małżeńskim, który stanowi podstawę dla całego systemu rodzinnego. Sposób funkcjonowania systemu małżonków oddziałuje na pozostałe podsystemy, a szczególnie na podsystem rodzicielski. Jakość granic pomiędzy małżonkami stanowi wzorzec i fundament dla jakości i sposobu egzystowania całego systemu rodzinnego ${ }^{44}$.

Dlatego poruszając wątek rozwoju uzależnienia jednostki od rodziny pochodzenia, należy przede wszystkim zwrócić uwagę na charakter relacji pomiędzy małżonkami, ponieważ ta relacja stanowi podstawę całego systemu rodzinnego, będącego źródłem omawianego uzależnienia. Jakość funkcjonowania systemu małżeńskiego znajduje konsekwencje w oddziaływaniach wychowawczych rodziców wobec dzieci, zaś owe oddziaływania skutkują reakcjami dzieci w postaci określonych stanów emocjonalnych, zachowań oraz sposobów społecznego funkcjonowania w dorosłym życiu.

Poniższy opis rozwoju i znaczenia uzależnienia jednostki od rodziny pochodzenia jest próbą ukazania procesu, mechanizmów oraz konsekwencji tego uzależnienia, w oparciu o model funkcjonowania małżonków, podejmowanych przez nich stylów wychowawczych oraz reakcji dzieci na stosowane wobec nich praktyki wychowawcze.

42 A.I. Brzezińska, K. Appelt, B. Ziółkowska, Psychologia rozwoju człowieka, Gdańskie Wydawnictwo Psychologiczne, Sopot 2016, s. 209.

43 Tamże, s. 207-208.

44 D. Field, Osobowości rodzinne... dz. cyt., s. 28-29. 


\section{Rodzina nadopiekuńcza}

Małżonkowie tworzący rodzinę nadopiekuńczą, celem zachowania komfortu rodzinnego oraz małżeńskiego kompromisu, unikają konfliktów na zasadzie ulegania, przemilczania pojawiających się małżeńskich i rodzinnych problemów oraz rezygnowania z własnych myśli i uczuć. Uwaga małżonków głównie skupiona jest na dzieciach, co sprawia, że system małżeński jest osłabiony na rzecz systemu rodzicielskiego $0^{45}$.

Model wychowawczy podejmowany przez opiekuńczych rodziców można określić jako pobłażliwy, polegający przede wszystkim na dawaniu i uleganiu. Charakterystyczne cechy takiego stylu wychowawczego to wysoki poziom okazywanego dziecku ciepła oraz niski poziom kontroli i dyscypliny. Wysoki poziom rodzicielskiego ciepła objawia się przede wszystkim poprzez nadmiernie ochranianie dziecka, wyręczanie go w obowiązkach oraz ratowanie z opresji i związane z tym uniemożliwianie poniesienia przez dziecko konsekwencji jego niewłaściwych zachowann ${ }^{46}$. Choć nadopiekuńczy rodzice nie pozwalają na wszystko swoim dzieciom, to jednak zwykle nie radzą sobie w zakresie egzekwowania ustalonych zasad, a w pełnieniu swych rodzicielskich ról sprawiają wrażenie, jakby potrzebowali pozwolenia od dziecka na zastosowanie wychowawczych praktyk i dyscyplinujących interwencji. Rodzice, podejmując niemalże wszystkie decyzje za dziecko, nie wymierzając mu żadnych kar oraz nie stawiając mu wymagań, hamują w nim rozwój podmiotowości, samodzielności i odpowiedzialności ${ }^{47}$.

Pobłażliwy styl rodzicielski, a szczególnie nadmierne ochranianie, kształtuje u dziecka postawę egocentryzmu oraz przekonanie, ze zawsze i wszystko będzie układać się według jego woli. Dzieci odbierające taki styl wychowawczy na etapie wczesnoszkolnym zwykle są roszczeniowe, samolubne i niecierpliwe, z czym związane są trudności dziecka w zakresie relacji społecznych, zarówno z rówieśnikami, jak i nauczycielami. W wieku szkolnym przejawiają zachowania antyspołeczne oraz osiągają słabsze rezultaty w nauce. Jako nastolatki, mając osłabione poczucie podmiotowości, w sytuacji porażki czy też odrzucenia przez grupę będą stosowali ucieczki, izolując się od społeczeństwa, gdyż ich poczucie wartości głównie opiera się na akceptacji i aprobacie ze strony środowiska ${ }^{48}$.

45 M. Ryś, Systemy rodzinne... dz. cyt., s. 14.

46 J.N. Butcher, J.M. Hooley, S. Mineka, Psychologia zaburzeń, Gdańskie Wydawnictwo Psychologiczne, Sopot 2018, s. 126.

47 M. Ryś, Systemy rodzinne... dz. cyt., s. 14-15.

48 J.N. Butcher, J.M. Hooley, S. Mineka, Psychologia zaburzeń... dz. cyt., s. 127. 
Dziecko wywodzące się z rodziny nadopiekuńczej jako dorosła osoba obawia się, że nie poradzi sobie w samodzielnym życiu, dlatego też moment opuszczenia domu rodzinnego odwlekany jest do maksimum. Rodzice, hamując w dziecku rozwój samodzielności i odpowiedzialności, nie stworzyli mu warunków do tego, by nauczyło się podejmowania decyzji i ponoszenia konsekwencji swoich działan, tym samym uzależniając je od siebie ${ }^{49}$. Konsekwencją uzależnienia od rodziny pochodzenia może być ukształtowanie osoby o zawyżonej samoocenie, przesadnie skoncentrowanej na sobie i własnych potrzebach, a co za tym idzie - mającej znaczne trudności ze społecznym przystosowaniem. Objawem uzależnienia może być także ciągłe poszukiwanie aprobaty i bezpieczeństwa, stąd też zwykle osoby te wiążą się z opiekuńczymi i zdecydowanymi partnerami, którzy będą sprawiać, że osoba uzależniona mentalnie będzie mogła doświadczać rodziny pochodzenia, gdzie otaczana była nadmierną troską i ochroną ${ }^{50}$.

\section{Rodzina uwikłana}

Małżonkowie tworzący system rodziny uwikłanej traktują związek jako jeden ze społecznych standardów na zasadzie odgrywania ról męża i żony. Jednak pod zewnętrzną fasadą serdecznego odnoszenia się do siebie oraz współdziałania kryje się brak miłości i autentycznej troski. Choć małżonkowie nie pokazują tego na zewnątrz, to w rzeczywistości są nieszczęśliwi, a wobec siebie zdystansowani ${ }^{51}$.

Osłabiona relacja małżeńska, związana z niezaspokojonymi potrzebami emocjonalnymi partnerów, negatywnie oddziałuje na system rodzicielski w postaci nadmiernej ingerencji rodziców w sprawy dzieci, nie pozostawiając im przestrzeni na jakąkolwiek intymność i indywidualność. Styl wychowawczy cechuje przesadna i nieustanna kontrola dziecka, które jest wykorzystywane przez jednego lub obydwoje rodziców celem zaspokojenia swoich psychicznych potrzeb. Rodzice, zawłaszczając dziecko, uzależniają je od siebie, stosując takie metody, jak: odwoływanie się do rodzinnej lojalności, wzbudzanie w nim poczucia winy, oskarżanie czy też niedopuszczanie prywatnych myśli przez demaskowanie mimiki twarzy lub tonacji głosu ${ }^{52}$.

Dziecko wzrastające w systemie rodziny uwikłanej staje się ofiarą niedojrzałości emocjonalnej swoich rodziców oraz stosowanych przez nich metod kontroli i manipulacji. Nieświadome dziecko, u którego ciągle wzbudzane jest poczucie

\footnotetext{
49 D. Field, Osobowości rodzinne... dz. cyt., s. 62-63; 65-68.

50 A.I. Brzezińska, K. Appelt, B. Ziółkowska, dz. cyt., s. 213.

51 D. Field, Osobowości rodzinne... dz. cyt., s. 85.

52 Tamże, s. 86-87.
} 
winy oraz wychowywane w duchu bezwzględnej lojalności wobec rodziny, stara się sprostać wszystkim oczekiwaniom rodziców, przez co traci swój indywidualizm, podmiotowość, jak również kontakt ze swoimi uczuciami i potrzebami. Całkowite podporządkowanie swojego Ja rodzicom rzutuje także na relacje z rówieśnikami oraz funkcjonowanie w grupie, gdzie dziecko wykazuje społeczny niedorozwój, gdyż stale odgaduje pragnienia innych celem dostosowania do nich, a nawet wręcz oczekuje wytycznych od grupy odnośnie do tego, co powinno mówić i robićs ${ }^{3}$.

Pomimo fizycznego opuszczenia domu, w sensie psychicznym odejście dziecka z Rodziny uwikłanej nie istnieje. Dziecko, nawet osiągnąwszy dorosłość, nadal jest kontrolowane i szantażowane przez rodziców, którzy ciągle odwołują się do poczucia lojalności względem siebie. Stąd też człowiek pochodzący z tego typu rodziny ze względu na niewykształconą podmiotowość i samodzielność nie jest w stanie rozpocząć niezależnego życia. Postawę dostrajania się do innych i spełniania ich oczekiwań, której wyuczył się w relacji z rodzicami, ujawnia także we wszelkich relacjach społecznych, z rówieśnikami, partnerem czy pracodawcą ${ }^{54}$.

Tak więc uzależnienie jednostki od rodziny pochodzenia dokonuje się w toku procesu zatracania jej odrębności i podmiotowości, dla którego kontekstem jest określony system funkcjonowania rodziny, charakteryzujący się nadmierną ilością ciepła i uczuć, deficytem szczerej komunikacji, przesadną ingerencją rodziców w życie dziecka oraz brakiem odpowiednich interwencji rodzicielskich sprzyjających rozwojowi kompetencji indywidualności i samodzielności u dziecka.

Wyniki badań dotyczących związku pomiędzy wzrastaniem w tych rodzinach dysfunkcyjnych, w których rodzice okazują wobec dzieci zbyt wielką ilość ciepła, w skrajnej formie uzależniając je od siebie oraz nieustannie je kontrolując a jakością psychospołecznego funkcjonowania jednostki, potwierdzają destruktywny wymiar przesadnie bliskich relacji rodzinnych. Im bardziej w rodzinie brakuje granic, a co za tym idzie - przestrzeni na samodzielność i prywatność, osoby wzrastające $\mathrm{w}$ takim modelu rodzinnym odznaczają się znacznymi problemami w podjęciu samodzielnego życia, szczególnie w zakresie psychicznego i społecznego funkcjonowania poza kontekstem rodzinnym.

Omawiane rezultaty badań wskazują, że im bardziej rodzinę cechuje zbytnia przepuszczalność i elastyczność granic, tym bardziej osoby wzrastające w takim modelu rodzinnym nie potrafią bronić własnych praw, godzą się na krzywdzące traktowanie, obarczają się konsekwencjami zachowań i działań innych osób oraz

53 Tamże, s. 87-88.

54 A.M. Strzeszewska, System rodziny pochodzenia a poczucie własnej wartości i oczekiwania od małzeństwa u młodych dorosłych, „Kwartalnik Naukowy Fides et Ratio” 2014, nr 3(19), s. 111. 
silniej doświadczają poczucia braku bezpieczeństwa, co jednocześnie wiąże się $\mathrm{z}$ nieustanną chęcią kontrolowania innych ingerując $\mathrm{w}$ ich życie prywatne. Osoby te odznaczają się także obniżonym poziomem nadziei na sukces, brakuje im przekonania na temat swych kompetencji, a także wykazują brak determinacji i pewności odnośnie do swoich możliwości w uzyskaniu zamierzonego celu ${ }^{55}$.

Takie osoby odznaczają się również deficytem odporności psychicznej. W obliczu trudności zniechęcają się, czują się osamotnieni, nie radzą sobie z silnymi emocjami, nie szukają rozwiązań. Długotrwale i boleśnie rozpamiętują porażki oraz życiowe zranienia ${ }^{56}$.

Wzrastanie w rodzinie uzależnionej ma także związek z oceną jakości związku, jak również idealnym wyobrażeniem na jego temat. Im bardziej rodzice kontrolowali dziecko ingerując w całość jego życia osobistego, tym niżej osoba wzrastająca w takim systemie ocenia jakość swojego związku, a także tym słabsze posiada idealne wyobrażenie na jego temat ${ }^{57}$.

\section{Podsumowanie}

Uzależnienie od rodziny pochodzenia opiera się na zbyt intensywnych niewidzialnych więziach, łączących jednostkę z jej rodziną generacyjną, egzystującą według określonego systemu, który w swym funkcjonowaniu wytwarza mechanizmy wiążące i uzależniające wzrastające w nim osoby. Systemami rodzinnymi stanowiącymi źródło omawianego uzależnienia są te, które w toku swego oddziaływania na przynależące do nich jednostki nie umożliwiają im rozwoju w zakresie ukształtowania w nich komponentów zdrowej osobowości, takich jak: podmiotowość, inicjatywa, samodzielność i odpowiedzialność. Wspomniane mechanizmy uzależniające jednostkę związane są przede wszystkim z oddziaływaniami wychowawczymi podejmowanymi przez rodziców wobec dzieci. Jakość i metody stylu wychowawczego są uwarunkowane modelem funkcjonowania systemu małżeńskiego. Osłabiona relacja między partnerami negatywnie rzutuje na tworzony przez nich system rodzicielski. Brak szczerej komunikacji oraz autentycznej troski, ukrywane pod fasadą szczęśliwego związku, świadczy o niedojrzałości emocjonalnej rodziców, którzy wykorzystują swe dzieci do zaspokojenia psychicznych potrzeb, zwłaszcza potrzeby bliskości i więzi. Podejmowany przez

55 Tamże, s. 121-123.

56 M. Ryś, Odporność psychiczna i relacje interpersonalne osób wzrastających w różnych systemach rodzinnych, Mazowieckie Centrum Polityki Społecznej, Warszawa, 2017.

57 M. Dziedzic, System rodziny pochodzenia a jakość związu matżeńskiego, „Kwartalnik Naukowy Fides et Ratio” 2016, nr 4(28), s. 47-69. 
nich styl rodzicielski cechuje zbyt wielka elastyczność i przepuszczalność granic lub zupełny ich brak pomiędzy podsystemami rodziców i dzieci. Niepozostawianie dziecku przestrzeni na jego odrębność i prywatność generuje proces zatracania jego indywidualności, który dokonuje się w ramach przesadnej ingerencji rodziców w sprawy dziecka, nadmiernie okazywanego mu ciepła, wyręczania go w jego obowiązkach, uniemożliwiania mu podejmowania własnych decyzji i wyborów oraz ponoszenia ich konsekwencji. „Bombardowanie miłością” wywołuje w dziecku nadmierne poczucie wdzięczności wobec rodziców, z którego wyrasta poczucie lojalności rodzinnej, stanowiące jedną z naczelnych zasad życia rodzinnego w omawianych uzależniających systemach rodzinnych. Dziecko na kolejnych etapach rozwoju, również jako nastolatek i dorosła osoba, czuje się zobligowane do spłacenia długu wdzięczności swoim rodzicom oraz do wywiązania się z lojalności wobec nich. Lojalność rodzinna, która w swej patologicznej odmianie jest zbyt silną i uzależniającą więzią, uniemożliwia podjęcie samodzielnego i odpowiedzialnego życia, dlatego też osoba pochodząca z uzależniającej rodziny, bez wykształconej podmiotowości jest słabo przystosowana społecznie oraz posiada ogromne problemy w zakresie sprawczości, decyzyjności oraz podjęcia zdrowych i trwałych relacji interpersonalnych, szczególnie małżeńskich i rodzinnych. Jednostka, która tworzy rodzinę prokreacyjną, jednocześnie posiadając silne poczucie lojalności wobec rodziny generacyjnej, przeżywa konflikt lojalnościowy, który stanowi źródło wielu napięć, konfliktów i patologii życia rodzinnego. Osoba, która jest nadmiernie związana emocjonalnie z rodziną pochodzenia, niejako ciągle w niej tkwiąc, na zasadzie dziedzictwa międzypokoleniowego wnosi to przywiązanie do rodziny własnej. Zasada dziedzictwa i lojalności rodzinnych skłania jednostkę, by wszelkie długi wobec rodziny generacyjnej, a także wszelkie doznane od niej krzywdy spłacać i rekompensować, w sposób świadomy bądź nie, wobec rodziny prokreacyjnej.

\section{Bibliografia}

Bajkowski T., U źródeł tożsamości rodzinnej, Wydawnictwo Naukowe Scholar, Warszawa 2018.

Barbaro M. de, Struktura rodziny, w: Wprowadzenie do systemowego rozumienia rodziny, red. B. de Barbaro, Collegium Medicum UJ, Kraków 1999, s. 45-55.

Bertalanffy L., Ogólna teoria systemów, Polskie Wydawnictwo Naukowe, Warszawa 1984.

Braun-Gałkowska M., Psychologiczna analiza systemów rodzinnych osób zadowolonych i niezadowolonych z matżeństwa, Towarzystwo Naukowe KUL, Lublin 1992. 
Brzezińska A.I., Appelt K., Ziółkowska B., Psychologia rozwoju człowieka, Gdańskie Wydawnictwo Psychologiczne, Sopot 2016.

Butcher J.N., Hooley J.M., Mineka S.,Psychologia zaburzeń, Gdańskie Wydawnictwo Psychologiczne, Sopot 2018.

Dziedzic M., System rodziny pochodzenia a jakość zwiazku matzeńskiego, „Kwartalnik Naukowy Fiedes et Ratio”, 2016, nr 4(28), s. 47-69.

Field D., Osobowości rodzinne, Oficyna Wydawnicza, Logos, Warszawa 1999.

Gawęcka M., Poczucie osamotnienia dziecka w rodzinie, Wydawnictwo Adam Marszałek, Toruń 2011.

Goldenbeg H., Goldenbeg I., Wydawnictwo Uniwersytetu Jagiellońskiego, Terapia rodzin, Kraków 2006.

Grzesiuk L., Jakubowska U., Terapia systemowa, w: Psychoterapia. TeoriaPodręcznik akademicki, red. L. Grzesiuk, Wydawnictwo Naukowe Eneteia, Warszawa 2005, s. 189-197.

Kołbik I., Lojalność rodzinna, w: Wprowadzenie do systemowego rozumienia rodziny, red. B. de Barbaro, Collegium Medicum UJ, Kraków 1999, s. 78-84.

Namysłowska I., Terapia rodzin, Wydawnictwo Instytutu Psychiatrii i Neurologii, Warszawa 1997.

Pietras T., Współczesne nurty $w$ terapii rodzin, w: Psychologia rodziny, red.I. Janicka, H. Liberska, Polskie Wydawnictwo Naukowe, Warszawa 2014, s. 527-536.

Plopa M., Psychologia rodziny: teoria i badania, Oficyna Wydawnicza Impuls Kraków 2007.

Przybylska E., Wajsprych D., Uczenie się i rodzina. Perspektywa andragogiczna, Wydawnictwo CeDeWu, Warszawa 2018.

Radochoński M., Psychoterapia rodzinna w ujęciu systemowym, Wydawnictwo Wyższej Szkoły Pedagogicznej w Rzeszowie, Rzeszów 1984.

Ryś M., Odporność psychiczna i relacje interpersonalne osób wzrastajacych w różnych systemach rodzinnych, Mazowieckie Centrum Polityki Społecznej, Warszawa 2017.

Ryś M., Systemy rodzinne. Metody badań struktury rodziny pochodzenia i rodziny własnej, Centrum Metodyczne Pomocy Psychologiczno-Pedagogicznej, Warszawa 2001.

Strzeszewska A.M., System rodziny pochodzenia a poczucie własnej wartości i oczekiwania od matżeństwa u młodych dorostych, „Kwartalnik Naukowy Fides et Ratio" 2014, nr 3(19), s. 105-128.

Świętochowski W., Rodzina w ujęciu systemowym, w: Psychologia rodziny, red. I. Janicka, H. Liberska, Polskie Wydawnictwo Naukowe, Warszawa 2014, s. $22-45$. 
Wolska M., Lojalność rodzinna, w: Kontakty z ludźmi 'innymi' jako problem wychowania, opieki i resocjalizacji, red. B. Kosek-Nita, D. Raś, Wydawnictwo Uniwersytetu Śląskiego, Katowice 2000, s. 49-60.

Wolska M., Problem lojalności rodzinnej a anoreksja psychiczna, „Przegląd Lekarski” 2004, nr 64 (11), s. 1284-1287.

\title{
Adam Grabowski: Family of origin dependence
}

\begin{abstract}
Summary
The basic and most important social context for a developing individual is the family, which is the main socialization environment for individuals who grow up in the family, but can also be a source of their mental disorders and social maladjustment. One of the family factors generating difficulties for the individual in terms of psychosocial functioning, the bond between the individual and his or her family of origin is too strong and addictive. This excessive attachment to the generational family usually stems from a sense of loyalty, which, in its pathological variety, destructively affects many areas of an individual's life and functioning. The main source of dependence on the family of origin is the family itself, together with a specific system of functioning which equips the growing individual with components of a healthy or disturbed personality. This article deals with the issue of family loyalty and related addictive family ties; points to family systems that generate too strong an attachment to a generational family in people who grow in it; and shows the importance of this attachment for the psychosocial functioning of an addicted individual in this context.
\end{abstract}

Keywords: family loyalty, family systems, overprotective family, entangled family 